\title{
Perancangan Pengukur Kekuatan Motor Brushless Berbasis ESP8266
}

\author{
Dedy Hermanto*1 \\ ${ }^{1}$ AMIK MDP; Jalan Rajawali No. 14, Palembang \\ ${ }^{3}$ Jurusan Teknik Komputer, AMIK MDP, Palembang \\ e-mail:*dedy@mdp.ac.id
}

\begin{abstract}
Abstrak
Dunia aeromodelling saat ini dapat dibilang sedang berkembang pesat, berbagai jenis pengembangan teknologi merambah didunia ini. Penghobi dunia aeromodelling juga cukup banyak, hal ini ditandai dengan bermunculan orang-orang yang bermain aeromodelling. Ketika bicara membuat sebuah airframe yang berhubungan dengan aeromodelling, terkadang membutuhkan aktuator (motor listrik) dalam hal ini motor brushless. Motor jenis ini banyak sekali digunakan dan juga saat ini banyak sekali tersedia dipasaran. Tetapi terkadang ketika membeli motor jenis ini tidak terdapat spesifikasi motor yang jelas untuk kemampuan motor dan kombinasi propeller yang digunakan. Penelitian ini bertujuan mengetahui kemampuan maksimal gaya dorong sebuah motor brushless dengan kombinasi propeller yang berbeda. Pengujian ini dilengkasi dengan ESP8266 sebagai otak pemroses data, Load Cell ditambah modul HX711 dan sensor arus dan daya digunakan untuk memantau kemampuan motor. Penelitian ini menggunakan metodologi Prototyping. Hasil yang didapat dalam penelitian pengukur kekuatan motor brushless ini yaitu mendapatkan kemampuan maksimal dimana setiap kecepatan motor (Throttle) dinaikkan maka akan menghasilkan nilai kemampuan daya angkat meningkat. Hasil lain yaitu penggunaan jenis propeller dari ukuran dan jenis berbeda akan mendapatkan kemampuan daya angkat yang berbeda.
\end{abstract}

Kata kunci-Aeromodelling, Thrust Motor, Brushless, ESP8266, Load Cell, HXT711, Prototyping

\begin{abstract}
The world of aeromodelling today is arguably growing rapidly, various types of technology developments penetrated in this world. The hobbyist of the world of aeromodelling is also quite a lot, it is related to people who play aeromodelling. When aeromodeller make an airframe associated with aeromodelling, you need an actuator (electric motor) in this case brushless motor. This type of motor now is a lot of type and also now a lot of in the market. But there are some motor wright now there where no information about combination of motor and propeller. This study shows that push a brushless motor with a combination of different propellers. This report is punctuated with ESP8266 as a brain data processor, Load Cell plus HX711 module and current sensor etc. to access motor capability. This research uses Prototyping methodology. The result in this research to get the maximum capability of brushless motor, it is related to speed of motor (Throttle) is raised then it will result in increased lift capability values. Another result is the use of propeller types of different sizes and types that will result in different lift capabilities.
\end{abstract}

Keywords—Aeromodelling, Thrust Motor, Brushless, ESP8266, Load Cell, HXT711, Prototyping 


\section{PENDAHULUAN}

Dunia aeromodelling merupakan suatu dunia yang menjadi wadah setiap orang untuk menyalurkan hobi dalam bidang dirgantara. Dunia kedirgantaraan ini banyak sekali cabangnya, yang salah satunya saat ini sangat berkembang pesat yaitu Multicopter dan pesawat model. Multicopter atau pesawat model merupakan salah satu jenis hobi yang sewaktu-waktu setiap perangkatnya dapat dibuat atau dirakit sendiri. Ketika penghobi aeromodelling ini menjadi orang yang biasa membuat, maka akan dihadapkan pada beberapa permasalahan pengetahuan untuk mendukung pembuatan perangkat tersebut. Salah satu yang menjadi isu penting untuk membangun suatu perangkat multicopter atau pesawat model, sebagai aktuator yang digunakan adalah motor. Motor ini ketika digunakan oleh penghobi, maka harus ada kesesuaian antara spesifikasi kemampuan motor dengan airframe yang akan digunakan.

Ketika bicara motor yang digunakan, kebiasaan penghobi dunia ini menggunakan motor berjenis brushless, tetapi tidak menutup kemungkinan juga menggunakan motor berjenis brushed. Motor yang digunakan ini, dengan kombinasi propeller (baling-baling) akan menghasilkan kekuatan (thrust) untuk mengangkat beban yang dibuat. Akan tetapi kemampuan motor ini terkadang tidak mencukupi atau tidak diketahui kemampuan maksimalnya dengan menggunakan baling-baling tertentu, hal ini dikarenakan keterbatasan baling-baling atau tabel spesifikasi perangkat yang digunakan tidak sesuai.

Agar permasalahan yang dihadapi oleh penghobi dapat sedikit teratasi maka penulis dengan ini melakukan sebuah penelitian untuk dapat merancang sebuah perangkat yang dapat mengukur dan memberikan referensi terbaik bagi penghobi dunia ini. Hal ini dilakukan dengan harapan mampu membantu memberikan hasil yang terbaik untuk mendapatkan perangkat yang sesuai untuk model yang akan atau sedang dibuat. Beberapa hal yang harus diperhatikan ketika perancangan perangkat ini dilakukan.

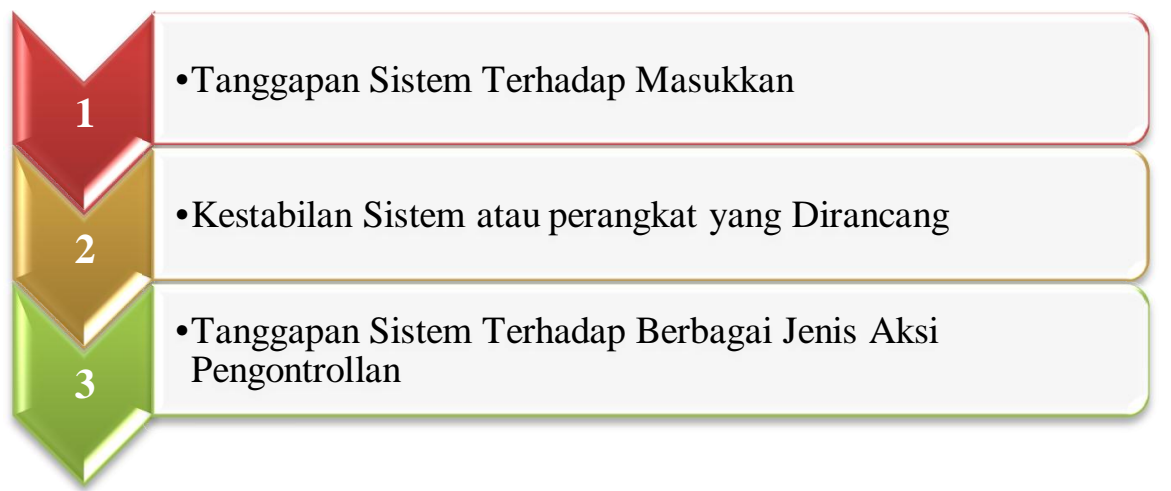

Gambar 1. Tanggapan Sistem, Sinyal Masukkan dan Aksi Kontrol

Dengan pemenuhan hal yang tersaji pada Gambar 1, dapat memberikan masukkan yang lebih baik bagi penggiat hobi ini. Hal ini dilakukan untuk memecahkan permasalahan yang biasa terjadi, dikarenakan data yang dikeluarkan pabrik terkadang tidak ada atau tidak sesuai ketika diimplementasikan. 


\section{METODE PENELITIAN}

\subsection{Motor Direct Current (DC)}

Merupakan perangkat yang mampu merubah energi listrik menjadi energi kinetik atau gerakan, masukan yang diberikan berupa suplai tegangan DC [1].

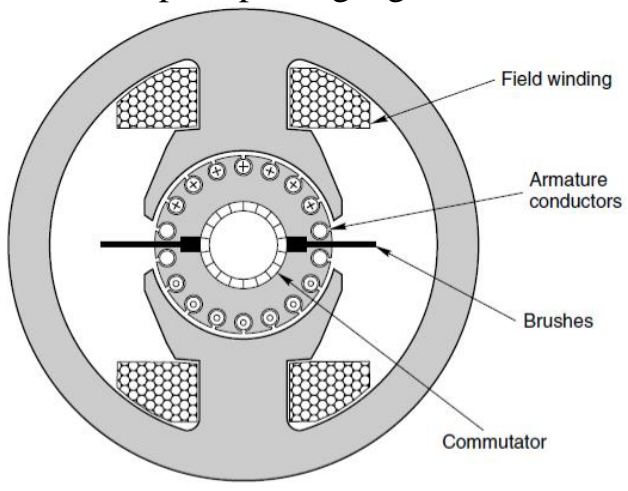

Gambar 2. Motor DC Konvensional

\subsection{Brushless DC (BLDC)Motor}

Motor DC Brushless merupakan jenis motor DC yang merupakan perubahan bentuk secara elektronik dengan menggunakan posisi umpan balik rotor sebagai penentu kapan harus mengubah arus [2]. Lilitan pada stator bekerja sebagai penghubung dengan menggunakan magnet permanen untuk menghasilkan pergerakan rotor berupa arus DC yang konstan.

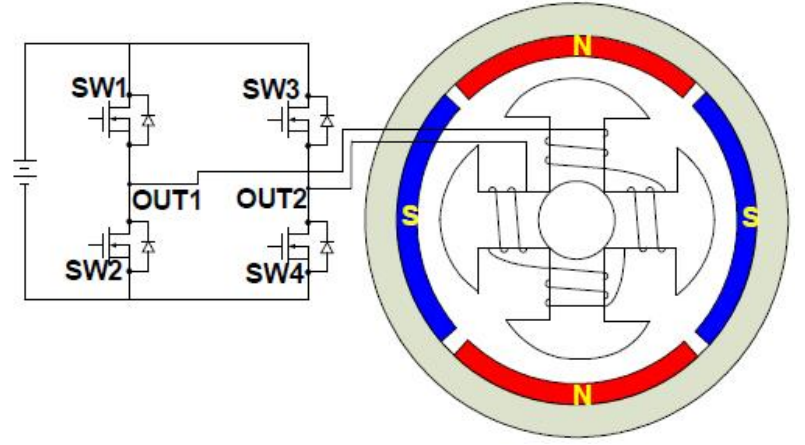

Gambar 3. BLDC Motor

\section{3 Load Cell}

Sensor yang digunakan untuk melakukan pendeteksian sebuah beban yang terpasang pada sebuah bidang, dimana prinsip pengukuran yang dilakukan yaitu dengan menggunakan metode tekanan [3].

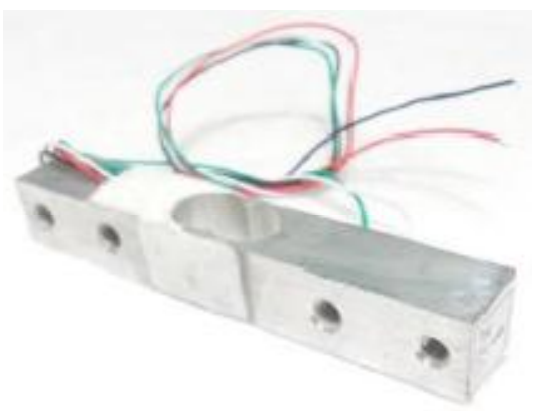

Gambar 4. Strain Gauge Load Cell 


\subsection{Oled Display}

Sebuah perangkat semikonduktor yang digunakan sebagai pemancar cahaya dimana perangkat ini terbuat dari lapisan organik. Oled merupakan perangkat yang bekerja seperti layar dengan memiliki ketebalan hanya sekitar $1 \mathrm{~mm}[4]$.

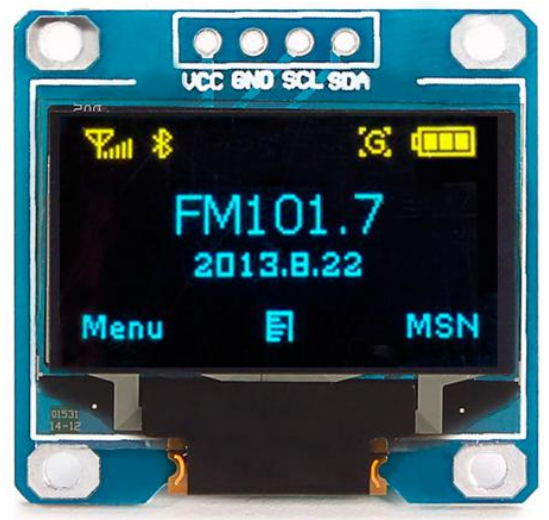

Gambar 5. Oled Display

\subsection{Node $M C U$}

Merupakan platform IOT yang memanfaatkan ESP8266 yang didalamnya tertanam wifi, sehingga untuk berkomunikasi dengan jaringan WLAN modul ini dapat langsung berkomunikasi baik sebagai client atau menjadi sebuah access point [5].

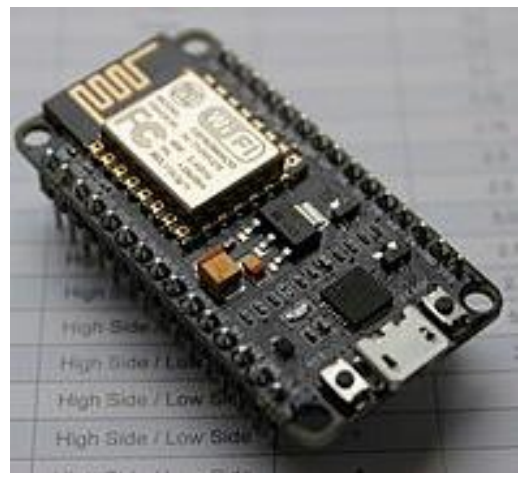

Gambar 6. Node MCU ESP8266

\subsection{Penelitian Terdahulu}

Dalam penelitian ini merupakan pengembangan atau penambahan beberapa penelitian yang sama bahasannya yaitu tentang kekuatan motor. Beberapa penelitian yang pernah membahas tentang brushless motor ini yaitu $[6,7,8,9]$. Dimana perolehan hasil penelitian berupa kekuatan motor dengan menggunakan mikrokontroller. Sedangkan dalam penelitian yang dikembangkan yaitu menggunakan 32 bit controller dan komunikasi via wifi dengan tampilan monitoring melalui web. 


\section{RANCANG BANGUN SISTEM}

\subsection{Rancangan Perangkat Keras}

Perancangan pengukur kekuatan motor brushless dilakukan dengan menentukan cara kerja perangkat yang akan dibangun sesuai dengan Gambar 7. Setelah memahami cara kerja sistem yang akan dibangun langkah selanjutnya adalah merancang perangkat yang akan dibangun dalam penelitian ini. Pada Gambar 8 dan 9 merupakan rancangan perangkat pengukur kekuatan motor Brushless yang akan digunakan pada penelitian ini.

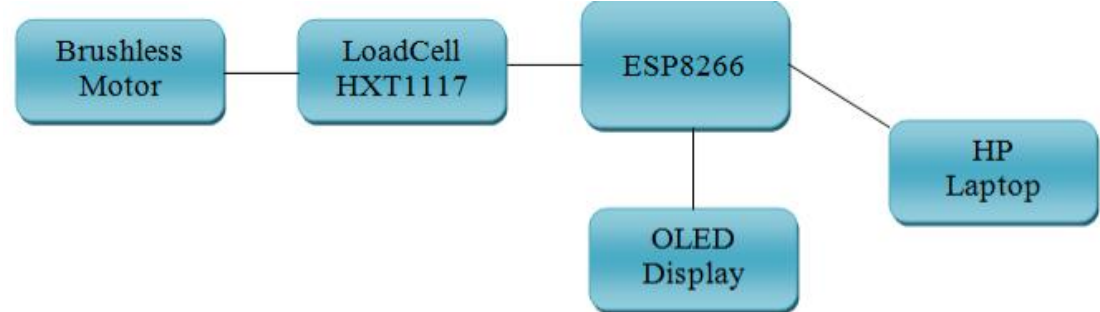

Gambar 7. Blok Diagram Sistem Pengukur Kekuatan Motor Brushless

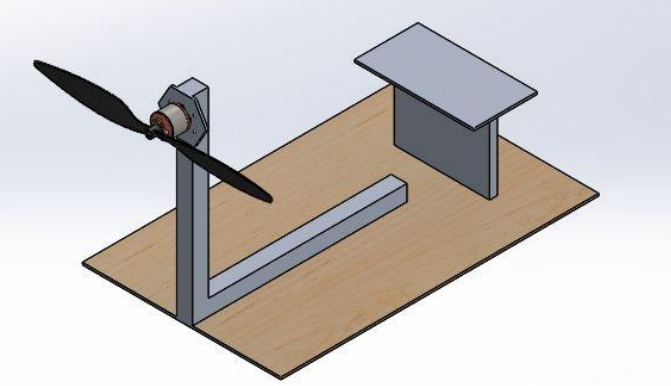

Gambar 8. Desain Perangkat Tampak Depan

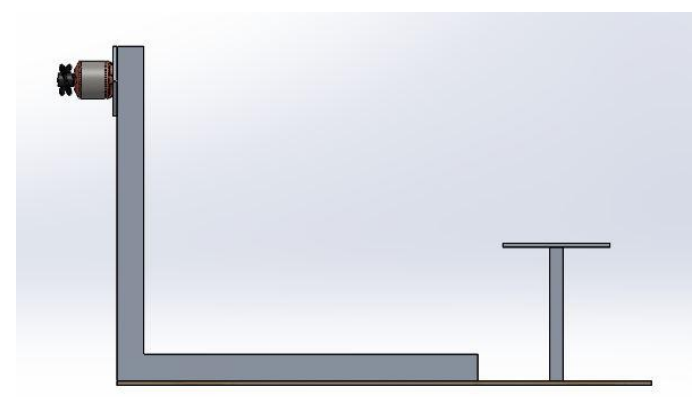

Gambar 9. Desain Perangkat Tampak Samping

\subsection{Rancangan Perangkat Lunak}

Agar perangkat dapat berjalan dengan baik, maka dibangun sebuah perangkat lunak yang mampu melakukan pengontrollan dan sinkronisasi terhadap perangkat yang berjalan. Terdapat 2 jenis perangkat lunak yang digunakan dalam penelitian ini yaitu perangkat lunak yang digunakan untuk sinkronisasi hardware dan perangkat lunak yang ditanamkan juga didalam hardware akan tetapi digunakan untuk menampilkan data dalam sebuah web melalui sinyal WiFi yang dihasilkan oleh ESP8266. Perangkat lunak yang berjalan yaitu tersaji pada Gambar 10, dimana sistem akan bekerja kemudian mendeteksi nilai yang dihasilkan oleh loadcell. Kemudian nilai tersebuat akan masuk ke perangkat ADC yaitu HX711, dimana nilai 
tadi akan dikonversi menjadi 24 bit data. Data yang terbaca akan ditampilkan di dua tempat yaitu tampilan pada loadcell dan tampilan pada web. Dimana web ini dapat diakses melalui perangkat apapun yang mampu menampilkan data melalui sebuah web.

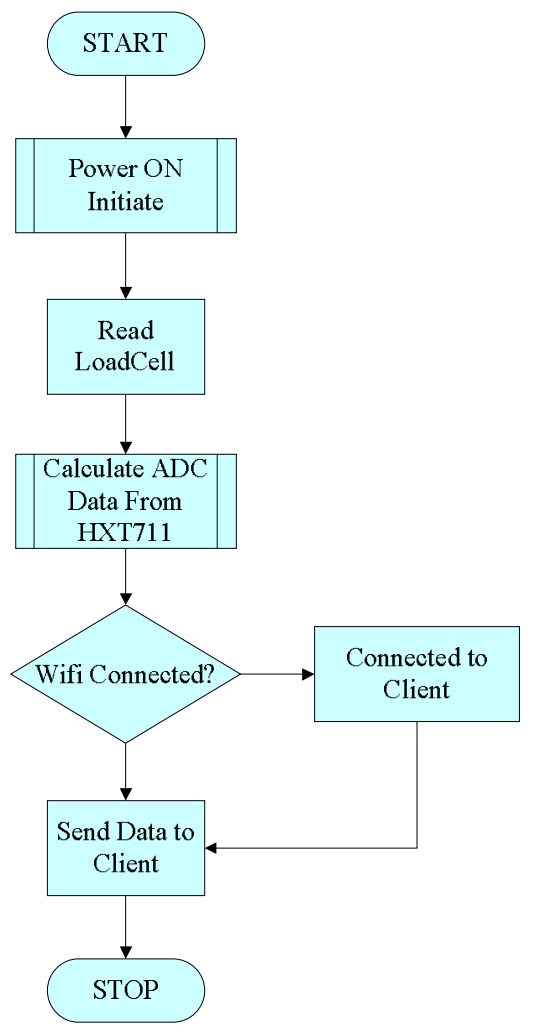

Gambar 10. Flowchart Program Sistem Pengukur Kekuatan Motor Brushless

Tampilan web yang digunakan dalam penelitian ini yaitu tersaji pada Gambar 11, dimana hasil yang ditampilkan berupa kekuatan daya dorong (Thrust) motor, yang dihasilkan dari daya yang dikeluarkan kombinasi antara motor dan propeller yang digunakan.

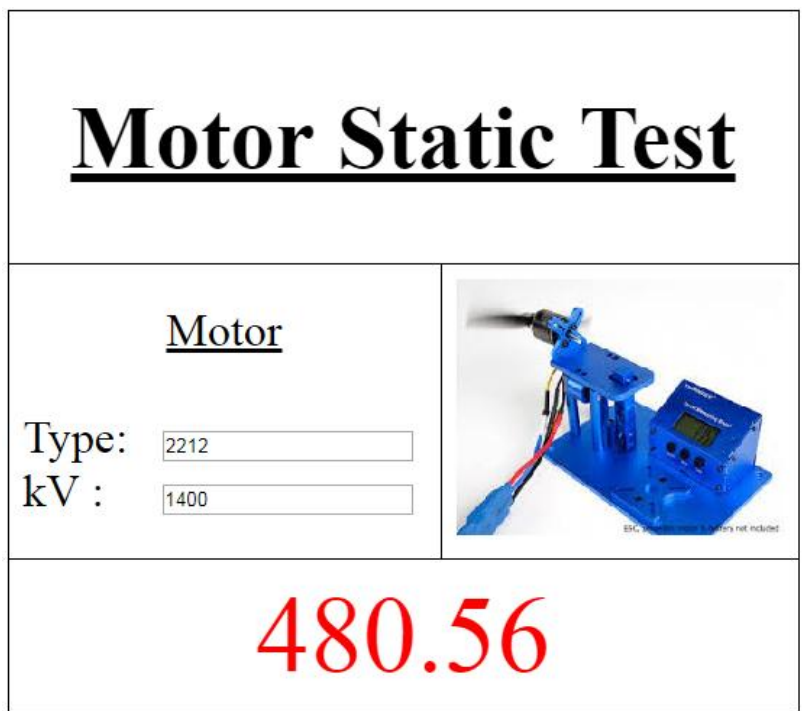

Gambar 11. Rancangan Perangkat Lunak Pengukur Kekuatan Motor Brushless 


\section{HASIL}

\subsection{Implementasi Sistem}

Dalam pengujian ini sebagai sumber tegangan untuk perangkat menggunakan sebuah baterai berjenis Litium Polimer (LiPo). Baterai ini digunakan sebagai suplai dari perangkat yang digunakan pada penelitian ini. Sebagai pengolah data dalam penelitian ini menggunakan ESP8266 yang didalamnya sudah terintegrasi $\mathrm{WiFi}$, sehingga dapat memudahkan untuk memancarkan hasil perhitungan yang didapat melalui sinyal WiFi. Pengontrollan kecepatan motor brushless dengan menggunakan potensio yang datanya telah diubah menjadi sinyal PPM, sinyal ini yang nantinya memutar kecepatan motor sesuai dengan yang akan digunakan pada penelitian.

Sebagai masukkan untuk ESP8266, menggunakan LoadCell dengan maksimal pengukuran sebesar 5000gr (5kg). Hasil pengukuran LoadCell ini dikonversi oleh sensor ADC 24 bit yaitu HX711. Keluaran HX711 yang kemudian diolah oleh ESP8266 untuk mendapatkan kekuatan daya dorong (thrust) dari motor yang digunakan.

Gambar 12 menunjukkan perangkat yang digunakan dalam penelitian ini yang telah siap digunakan untuk pengujian daya dorong motor brushless.

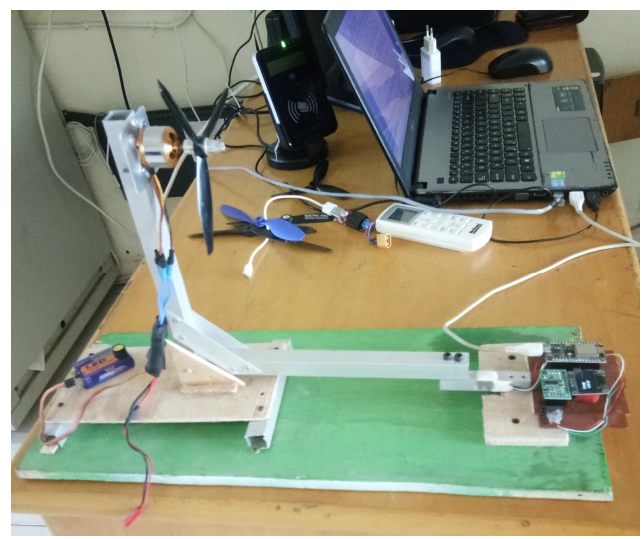

Gambar 12. Perangkat Penguji Kecepatan Motor Brushless

\subsection{Pengujian Sistem}

Pengujian sistem yang telah dibangun hanya menggunakan satu buah motor yang tidak memiliki nama produsen dengan tipe yang digunakan yaitu 2212/10T 1400kV. Motor yang digunakan dalam penelitian tidak memiliki data pabrik yang lengkap yaitu tentang kemampuan motor, kombinasi propeller motor dan kebutuhan konsumsi arus yang dibutuhkan motor. Dalam penelitian ini menggunakan 2 jenis propeller yaitu 3 blade $(5 \times 4$ dan $6 \times 4)$ dan 2 blade $(5 \times 4$ dan $6 x 4)$. Terdapat perbedaan kekuatan daya dorong yang didapat, dimana ketika kecepatan motor (Throttle) ditambah maka kemampuan daya angkat motor akan semakin meningkat baik ketika menggunakan propeller jenis 2 blade atau 3 blade. Hasil tersebut tersaji pada Tabel 1 dan 2.

Tabel 1. Pengujian Daya Dorong Propeller 2 Blade Dalam gr

\begin{tabular}{|c|c|c|}
\hline PPM (\%) & $\mathbf{5 x 4}$ & $\mathbf{6 x 4}$ \\
\hline 20 & 3 & 4 \\
\hline 40 & 25 & 31 \\
\hline 60 & 128 & 148 \\
\hline 80 & 280 & 310 \\
\hline 100 & 315 & 380 \\
\hline
\end{tabular}




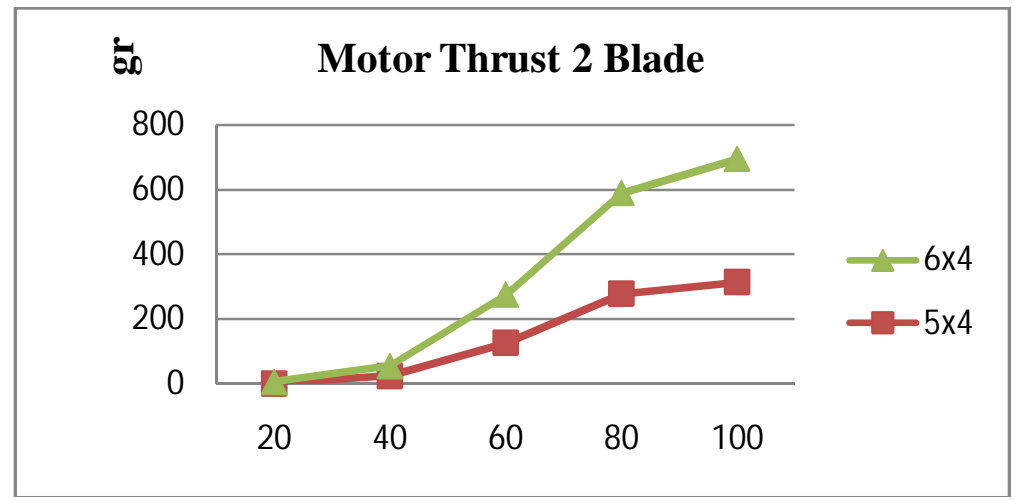

Gambar 13. Daya Dorong Motor Menggunakan Propeller 2 Blade

Tabel 2. Pengujian Daya Dorong Propeller 3 Blade Dalam gr

\begin{tabular}{|c|c|c|}
\hline PPM (\%) & $\mathbf{5 x 4}$ & $\mathbf{6 x 4}$ \\
\hline 20 & 6 & 8 \\
\hline 40 & 46 & 49 \\
\hline 60 & 151 & 181 \\
\hline 80 & 289 & 364 \\
\hline 100 & 341 & 489 \\
\hline
\end{tabular}

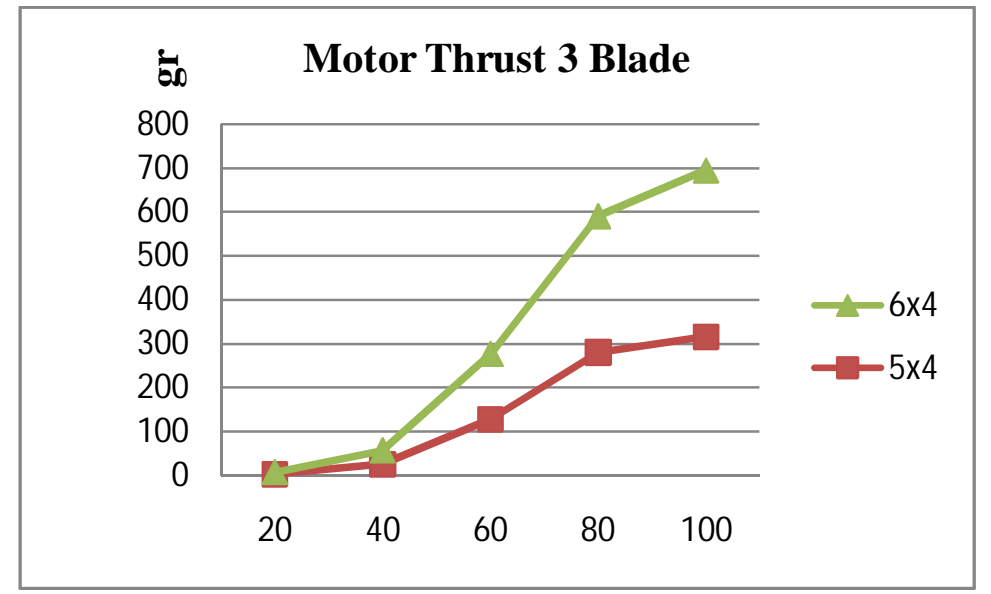

Gambar 14. Daya Dorong Motor Menggunakan Propeller 3 Blade

\section{KESIMPULAN}

Dari hasil penelitian yang telah dilakukan didapat beberapa kesimpulan yaitu:

- Penggunaan ESP8266 dengan WiFi yang telah terintegrasi dapat mempermudah memantau data yang ditampilkan kedalam beberapa perangkat.

- Data hasil pengujian berupa Thrust motor menunjukkan setiap RPM Motor meningkat maka kekuatan daya angkat motor menjadi meningkat tersaji pada Gambar 13 dan 14 dari Grafik 1 dan 2. 
- Ukuran Propeller yang sama tetapi memiliki jumlah blade yang berbeda menghasilkan daya angkat yang berbeda.

\section{DAFTAR PUSTAKA}

[1] Hughes, A. 2006, Electric Motor and Drivers Fundamental Types and Application, Newnes, Inggris.

[2] Zhao, J., \& Yu, Y. 2014, Brushless DC Motor Fundamental, MPS, GhuangZo.

[3] Systems, T. 2015, www.tacunasystems.com. Retrieved Mei 31, 2018, from tacunasystems: https://tacunasystems.com/zc/the-essential-guide-to-load-cells.

[4] Nalwa, H. S. 2003, Handbook of Luminescence, Display Materials and Devices, Vol. 1 : Organic Light-Emitting Diodes. American Scientific, Los Angeles.

[5] Espressif. 2017, NodeMCU. Retrieved May 31, 2018, from https://nodemcu.readthedocs.io: https://nodemcu.readthedocs.io

[6] Brezina, A. J., \& Thomas, S. K. 2012, Measurement of Static and Dynamic Performance Characteristic of Small Electric Propulsion Systems, Dayton, Ohio, America.

[7] Kurniawan, T. W. 2016, Perancangan Kontroller Neural Network-PID Untuk Mengatur Kecepatan Motor DC Brushless, Surabaya, Jawa Timur, Indonesia.

[8] Randis, Dharmawan, I. B., \& Syahruddin. 2017, Rancang Bangun Alat Uji Gaya Dorong (Trust Force) Motor Brushless, Jurnal Teknologi Terpadu , 128-133.

[9] Sugiarto, T., Setyadewi, I. T., Marta, Y., \& Setyo P., G. 2015, Rancang Bangun Sistem Pengujian Motor Brushless Untuk Aplikasi SOLAR-LAPAN Surveilence UAV Berbasis $L A B V I E W$, Bogor, Indonesia. 